\title{
Determination of the serviceability of bridge upper structures (Case study: Sangsang River bridge at Tohpati-Kusamba highway, Bali)
}

\author{
I Nyoman Sutarja ${ }^{1}$ Ida Bagus Rai Widiarsa ${ }^{1}$, and I Made Alit Karyawan Salain ${ }^{1}$ \\ ${ }^{1}$ Department of Civil Engineering, Universitas Udayana, Denpasar, Indonesia
}

\begin{abstract}
The serviceability of upper structures of the Sangsang River Bridge during the designed period has decreased due to several factors such as environmental influences affecting the physical condition of the bridge, as well as the load that exceeds the designed capacity. Sangsang River Bridge needs to be maintained during the serviceability period in order to function optimally, safely and comfortably. The maintenance of the bridge begins with the examination of the existing condition of the bridge by utilizing Non-Destructive Test method using UPV Pundit PLLink 500 Digital tool. The data collected was then analysed to find out the serviceability of bridge structure. The analysed results showed that the value of concrete slab density was $17.8 \mathrm{MPa}$ and of the concrete girder was $18.1 \mathrm{MPa}$. This values were classified as a deficient criterion and therefore the serviceability needs to be increased. Recommendations for enhancing the bridge serviceability was strengthening using Fibre Reinforced Polymer (FRP). Using 2 Layer SEH-51A or equivalent 2 Layer of E-glass fibre was suggested for concrete slab, meanwhile the use of 2 Layer SCH-41 or equal to 2 Layer Carbon fibre was suggested for concrete girder.
\end{abstract}

\section{Introduction}

The construction of a bridge is required to connect two parts of a road that are separated by barriers such as deep valleys, river beds, lakes, irrigation channels, rivers, railroads, highways that are not in one plane. Sangsang River Bridge was built to connect two parts of the road that was separated by the Sangsang river on Tohpati - Kusamba road section +21.640 meters.

The serviceability of the structural elements of the Sangsang River bridge during its design period has decreased due to several factors, i.e. environmental effects such as corrosion, bridge physical condition, and loads which exceed the capacity of the design. Sangsang River bridge needs to be maintained during the design period

\footnotetext{
${ }^{1}$ Corresponding author: nsutarja_10@yahoo.com
} 
to function optimally, safely and comfortably. Maintenance is the handling activities in the form of rehabilitation and preservation improvement to obtain a more stable and longer serviceability of the bridge.

The maintenance activities of Sangsang River bridge must be supported by complete, accurate and actual data about the recent condition of the bridge in the field. To support the maintenance program, the first thing to do is investigating the condition of the bridge. The investigation was done by the use of specific equipment called Ultrasonic Pulse Velocity (UPV) Pundit PL-Link 500 digital tool [1]. The data obtained was the density condition of concrete which then can be indirectly correlated to concrete compressive strength. Based on the investigation data, the analysis was done as the basis for the improvement and reinforcement of the bridge structure. This paper is only limited to discussing the preservation improvement and strengthening of the upper building structure of the bridge, that are the beam and vehicle floor slab.

\section{Methods}

\subsection{Research location}

The bridge that was used as a case study is Sangsang River bridge located at Tohpati-Kusamba section +21.640 meters. The upper structural system is a prestressed concrete I-beam and reinforced concrete floor slab, as shown in Fig. 1.

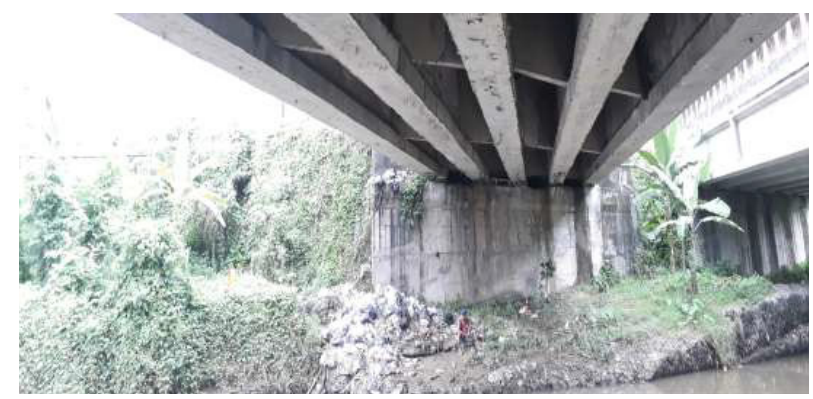

Fig. 1. Structural element of bridge upper structure.

\subsection{Scope of activities}

\subsubsection{Institutional survey and document review}

The technical documents of the structure owned by the owner of the bridge are very important to be observed before the field examination. The data sourced on the document must be verified. The documents include planning, drawings, and implementation drawings (As-built-drawing).

\subsubsection{Visual inspection}

Visual inspection was done on bridge elements and environmental conditions. Visual examinations could be used as data for types of damage that exist in the structural elements of the bridge and the factors causing them. 


\subsubsection{Concrete quality testing}

Concrete quality testing on the existing bridge was done by the Non-Destructive Test method, by using Ultrasonic Pulse Velocity (UPV) Pundit PL-Link 500 digital tool [1]. This tool can provide information about the condition of the surface or inner part of the concrete and can indirectly provide information about the value of compressive strength of the concrete.

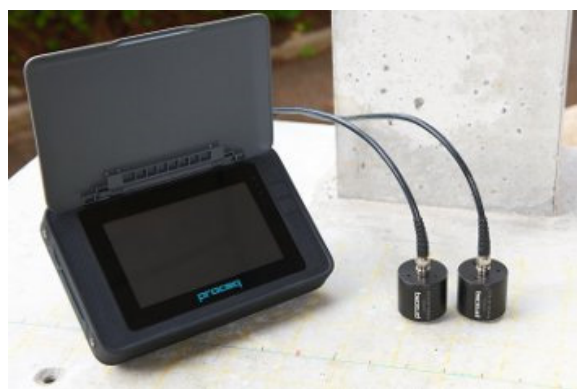

Fig. 2. Concrete density examination tool (UPV).

This device consists of transmitting wave signal transducer (transmitter) and receiver transducer (receiver). This tool is also equipped by a measuring device and time recorder needed by the wave to propagate from the transmitter to the receiver. The length of the wave path between the transmitter and the receiver could be identified so that the wave propagation velocity could be calculated. The type of transducer suitable for application on the concrete material is a transducer with a single frequency ranging from 20 to $150 \mathrm{KHz}$. Standard of this ultrasonic testing method can be seen on BS 4408 pt. 5 or ASTM C 597. Checking concrete with Indirect Test method is shown in Fig. 3c.

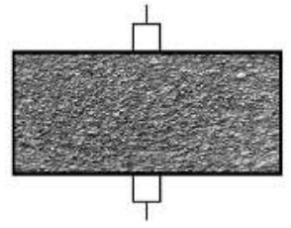

(a)

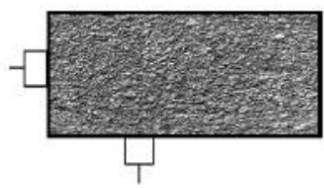

(b)

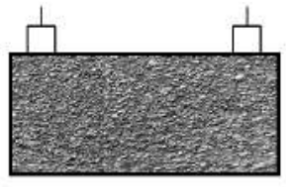

(c)

Fig. 3. Type of test using UPV Pundit tool: (a) direct, (b) semi direct, (c) indirect

\subsubsection{Strengthening of top building structures}

Strengthening the floor slab structure using GFRP (Glass Fiber Reinforced Polymer) is equivalent to Tyfo SEH-51A. While on the beam structure using GFRP is equivalent to Tyfo $\mathrm{SCH}-41$. The assumptions used to calculate the durability of the GFRP-amplified cross-section was based on ACI 440 [2].

\section{Results and discussion}

\subsection{Concrete quality}

The results of concrete density analysis with Ultrasonic Pulse Velocity (UPV) on the elements of floor slab and beam of the bridge are shown in Table 1 [3]. 
Table 1. UPV data processing recapitulation.

\begin{tabular}{|c|c|c|c|c|c|c|c|}
\hline $\begin{array}{c}\text { Structural } \\
\text { element }\end{array}$ & $\begin{array}{c}\text { Sample } \\
\text { ID }\end{array}$ & $\begin{array}{c}\text { Direct } \\
\text { Velocity } \\
\text { Pulse }\end{array}$ & $\begin{array}{c}\text { Poisson } \\
\text { ratio }\end{array}$ & $\begin{array}{l}\text { Density } \\
\left(\mathrm{kg} / \mathrm{m}^{3}\right)\end{array}$ & $\begin{array}{c}E_{\mathbf{c}} \\
(\mathrm{MPa})\end{array}$ & $\begin{array}{c}f_{\mathrm{c}} \\
(\mathbf{M P a})\end{array}$ & $\begin{array}{c}f, \\
\text { avg. } \\
\text { (MPa) }\end{array}$ \\
\hline \multirow{4}{*}{ Beam } & 180 & 2945 & 0.15 & 2400 & 19713 & 17.59 & \multirow{4}{*}{18.15} \\
\hline & 181 & 2975 & 0.15 & 2400 & 20117 & 18.3 & \\
\hline & 182 & 2953 & 0.15 & 2400 & 19821 & 17.78 & \\
\hline & 183 & 2998 & 0.15 & 2400 & 20429 & 18.89 & \\
\hline \multirow{4}{*}{ Slab } & 184 & 2987 & 0.15 & 2400 & 20280 & 18.62 & \multirow{4}{*}{17.83} \\
\hline & 185 & 2963 & 0.15 & 2400 & 19955 & 18.0 & \\
\hline & 186 & 2945 & 0.15 & 2400 & 19713 & 17.59 & \\
\hline & 187 & 2924 & 0.15 & 2400 & 19433 & 17.10 & \\
\hline
\end{tabular}

\subsection{Recapitulation of concrete compression strength}

The concrete compression strength was estimated based on the UPV test on slab and beam and the recapitulation is shown in Table 2.

Table 2. Estimated concrete compression strength.

\begin{tabular}{|c|c|c|c|}
\hline $\begin{array}{c}\text { Structural } \\
\text { elements }\end{array}$ & $\begin{array}{c}\text { Average } \\
\text { direct } \\
\text { velocity }(\mathbf{m} / \mathbf{s})\end{array}$ & $\begin{array}{c}\text { Everage } \\
\text { estimation of } \boldsymbol{f}_{\mathbf{c}} \\
\text { (MPa) }\end{array}$ & $\begin{array}{c}\text { Classification of the quality } \\
\text { of concrete on the basis of } \\
\text { Pulse Velocity }\end{array}$ \\
\hline Beam & 2968 & 18.15 & $<3000 \mathrm{~m} / \mathrm{s}=\mathrm{Bad}$ Condition \\
\hline Slab & 2955 & 17.83 & $<3000 \mathrm{~m} / \mathrm{s}=\mathrm{Bad}$ Condition \\
\hline
\end{tabular}

Table 3. Capacity and needs of slabs and block structures.

\begin{tabular}{|c|c|c|c|c|}
\hline $\begin{array}{c}\text { Structural } \\
\text { element }\end{array}$ & Internal force & Capacity & $\begin{array}{c}\text { Required } \\
\text { capacity }\end{array}$ & Condition \\
\hline \multirow{2}{*}{ Slab } & $\begin{array}{c}\text { Positive } \\
\text { Moment (+) }\end{array}$ & $\begin{array}{c}86.576 \\
(\mathrm{KN}-\mathrm{m})\end{array}$ & $\begin{array}{c}93.973 \\
(\mathrm{KN}-\mathrm{m})\end{array}$ & Not Ok \\
\hline \multirow{3}{*}{ Beam } & $\begin{array}{c}\text { Positive } \\
\text { Moment (+) }\end{array}$ & $\begin{array}{c}13079.6 \\
(\mathrm{KN}-\mathrm{m})\end{array}$ & $\begin{array}{c}13834.1 \\
(\mathrm{KN}-\mathrm{m})\end{array}$ & Not Ok \\
\cline { 2 - 5 } & Shear (-) & $\begin{array}{c}1216.2 \\
(\mathrm{KN})\end{array}$ & $\begin{array}{c}1444.4 \\
(\mathrm{KN})\end{array}$ & Not Ok \\
\hline
\end{tabular}

From the results, it can be seen that the value of concrete density on the floor slab is $17.83 \mathrm{MPa}$ with poor density criteria and the value of concrete quality density on the beam is $18.15 \mathrm{MPa}$ with poor density criteria. Based on these results, it can be identified that the quality of concrete has decreased significantly. The 
estimated compressive strength $\mathrm{f}_{\mathrm{c}}$, of concrete is $17.8 \mathrm{MPa}$ for floor slab and is 18.1 $\mathrm{MPa}$ for the beam, which then becomes the basis for structural retrofitting design.

\subsection{Capacity and needs of floor and beam layer structures}

Table 3 shows the capacity and required capacity of the structural elements. The analysis results show that the capacity of slabs and beams with their existing crosssection installed in the field are not sufficient to withstand the service load, therefore strengthening with external reinforcement is required [4].

\subsection{Recommended slab and beam reinforcement}

Strengthening on the floor slab structure using GFRP (Glass Fiber Reinforced Polymer) is equivalent to Tyfo SEH-51A, and on the beam structure using GFRP is equivalent to Tyfo SCH-41. Based on the retrofitting design, it is recommended to reinforce the slabs and beams using a number of layer of GFRP as in Table 4.

Table 4. Strengthening floor slabs and beams.

\begin{tabular}{|c|c|c|}
\hline Structural elements & Inner Force & Retrofitting \\
\hline Floor slab & $125.68(\mathrm{KN}-\mathrm{m})$ & 2 Layer Typo SEH-51A \\
\hline \multirow{2}{*}{ Beam } & $14438.09(\mathrm{KN}-\mathrm{m})$ & 2 Layer Typo SCH-41 \\
\cline { 2 - 3 } & $1833.4 \mathrm{KN}$ & 2 Layer Typo SCH-41 \\
\hline
\end{tabular}

\section{Conclusions}

Based on the analysis on Sangsang River Bridge, it can be concluded as follows. It is visible that floor slab and beam of the bridge have cracks and start being porous indicating degradation of the quality of concrete. The UPV test results show the concrete quality density of the slab was $17.83 \mathrm{MPa}$ that classifies as poor density criteria. For the concrete with quality density of the beam was $18.15 \mathrm{MPa}$, it classifies to poor density criteria. Estimation of concrete compressive strength or $\mathrm{f}_{\mathrm{c}^{\prime}}$ was $17.8 \mathrm{MPa}$ for floor slab and 18.1 MPa for the beam, which then becomes the basis for structural strengthening design. It is recommended that the reinforcement on the floor slab structure should use 2 GFRP layers equivalent to Typo SEH-51A, and on the beam structure using 2 GFRP layers equivalent to Typo SCH-41, for bending and shear.

\section{References}

1. K.H. Matlack, J.Y. Kim, L.J. Jacobs, J. Qu, J. of Nondestructive Evaluation 34, 1 (2015)

2. Computes and Structures Inc., CSI Analysis Reference Manual For SAP2000, ETABS, SAFE, and CSiBridge (Univ. Avenue, California, 2015)

3. A. Mostavi, N. Kamali, N. Tehrani, S-W. Chi, D. Ozevin, J.E. Indacochea, Measurement 106, 66 (2017)

4. S. Charhate, M. Subhedar, N. Adsul, J. of Soft Comp. in Civ. Eng. 2-3 (2018) 